\title{
Soybean Nodulation and Plant Response to Nitrogen and Sulfur Fertilization in the Northern US
}

\author{
Benjamin D. Cigelske ${ }^{1}$, Hans Kandel ${ }^{*}{ }^{(0)}$, Thomas M. DeSutter ${ }^{2}$ () \\ ${ }^{1}$ Department of Plant Sciences, North Dakota State University, Fargo, ND, USA \\ ${ }^{2}$ Department of Soil Sciences, North Dakota State University, Fargo, ND, USA \\ Email: ben.cigelske@ndsu.edu, ‘hans.kandel@ndsu.edu,Thomas.Desutter@ndsu.edu
}

How to cite this paper: Cigelske, B.D., Kandel, H. and DeSutter, T.M. (2020) Soybean Nodulation and Plant Response to Nitrogen and Sulfur Fertilization in the Northern US. Agricultural Sciences, 11, 592-607. https://doi.org/10.4236/as.2020.116037

Received: May 25, 2020

Accepted: June 21, 2020

Published: June 24, 2020

Copyright ( 2020 by author(s) and Scientific Research Publishing Inc. This work is licensed under the Creative Commons Attribution International License (CC BY 4.0).

http://creativecommons.org/licenses/by/4.0/ (c) (i) Open Access

\begin{abstract}
Soybean [Glycine $\max$ (L.) Merrill] seed yields in the northern United States may increase with the application of fertilizers; however Nitrogen $(\mathrm{N})$ may decrease root nodulation. This study was conducted to understand the impact of $\mathrm{N}$ and sulfur (S) fertilization on soybean nodulation, plant, shoot and root biomass. Two cultivars were planted in experiments across ten site-years during 2015-2016. Plant observations took place at the V4 and R4 soybean growth stages. There were $41 \%$ more nodules per plant at R4 compared to V4 (38.3 vs 27.2 nodules, respectively). Cultivars responded differently to $\mathrm{N}$ and $S$ fertilizer. The nodules per plant between the cultivars (30.3 vs 24.4 ) were different as well as the percent medium and large-sized nodules, which indicates the need to evaluate additional genotypes. Adding $\mathrm{N}$ decreased root nodulation (from 31.8 to 23.7 nodules per plant) and decreased nodule size but had no effect on plant, shoot or root mass. Averaged across $\mathrm{N}$ rates total plant mass was 2.26 and $11.36 \mathrm{~g}$ per plant at V4 and R4, respectively. Shoot mass, average across $\mathrm{N}$ rates was 1.77 and $9.65 \mathrm{~g}$ per plant at V4 and R4, respectively, and root mass, average across $\mathrm{N}$ rates was 0.49 and $1.71 \mathrm{~g}$ per plant at V4 and R4, respectively. Sulfur did not have an effect on nodules per plant but increased the percent medium size nodules at the R4 observation. There was no $\mathrm{N}$ by $\mathrm{S}$ interaction observed for nodule number, size of the nodules, and plant, root and shoot mass. As cultivars differed in their nodulation response to $\mathrm{N}$ and $\mathrm{S}$, additional research would be helpful to screen other cultivars.
\end{abstract}

\section{Keywords}

Soybean, Nitrogen, Sulfur, Nodulation, Shoot Mass, Root Mass 


\section{Introduction}

Over the last two decades soybean [Glycine max (L.) Merrill] cultivars have been developed, which are adapted to be planted in the northern soybean-growing region of the United States. Soybean yields have increased due to new cultivars, application of fertilizers and pesticides, and more intensive crop management practices. For example, the average North Dakota and Minnesota soybean yields have increased by 23.5 and $28.1 \mathrm{~kg} \cdot \mathrm{ha}^{-1} \cdot \mathrm{yr}^{-1}$, respectively, from 1970 through 2019 [1].

In Minnesota and the northern Great Plains (NGP), which includes eastern Montana, northeastern Wyoming, North Dakota and South Dakota, soybean is planted in mid-May and harvested in late September or early October. Improving fertilization practices could increase Minnesota and NGP average soybean yield. Presently, no N application is recommended for North Dakota and northern Minnesota, except as a rescue treatment [2].

As newly developed soybean cultivars with higher yield potentials are being grown, there are concerns to whether or not biological $\mathrm{N}_{2}$ fixation is capable of meeting increased plant $\mathrm{N}$ demands [3] [4]. Current knowledge states that soybeans acquire about $44 \%-72 \%$ of their $\mathrm{N}$ from $\mathrm{N}_{2}$ fixation and the remainder from residual soil fertilizer and $\mathrm{N}$ mineralization [5].

Based on a meta-analysis using peer-reviewed papers, $\mathrm{N}$ fertilized soybean field experiments had $44 \%$ lower biological $\mathrm{N}_{2}$ fixation compared to the unfertilized control [6]. Fertilizer $\mathrm{N}$ decreased soybean nodulation and increased aboveground plant dry matter [7]. Additionally, Heatherly [8] concluded that the application of $35 \mathrm{~kg} \cdot \mathrm{N} \cdot \mathrm{ha}^{-1}$ in the form of granular ammonium nitrate applied before V2 [9] did not increase yield. However, low rates of $\mathrm{N}$ at seeding have increased soybean yield and nodulation in some regions [7] [10] [11], possibly due to limited $\mathrm{N}$ fixation at the beginning of the season. The main source of $\mathrm{N}$ during early vegetative development is the utilization of $\mathrm{NO}_{3}^{-}-\mathrm{N}$ from the soil, which can be from soil mineralization or application of fertilizer [12]. However, $\mathrm{N}$ as incorporated ammonium sulfate (AMS) and broadcast incorporated urea at planting may not increase soybean yield in certain environments [13] [14]. Thus, identifying soil limiting environments and targeting those for $\mathrm{N}$ application may provide some increase in yield potential.

Sulfur is becoming deficient in soils due to the introduction of high yielding crop cultivars, the use of high-grade $S$ free fertilizers, and the reduced emission of S from industrial processes [15]. Soil S levels have decreased as S removal and yields of all major agricultural crops have increased, and deposition of $\mathrm{SO}_{4}-\mathrm{S}$ via rainfall, fertilizer, and pesticides has decreased [16] [17]. Although dry and wet $S$ deposition rates in the northern United States have remained fairly steady [18], above normal precipitation since 1993 has caused some S deficiencies in corn (Zea mays L.) in North Dakota [19]. Soils typically at risk for S deficiency include coarse-textured soils, soils low in organic matter, soils experiencing large amounts of rainfall in the fall or spring, and soils located on higher landscape 
positions [20]. Since many of the soils and parent materials in the NGP have gypsum $\left(\mathrm{CaSO}_{4} \cdot 2 \mathrm{H}_{2} \mathrm{O}\right)$ within them, $\mathrm{S}$ deficiencies, if they occur, will not likely be widespread [21]. Between deposition, soil-derived S from secondary minerals, and mineralization of soil organic matter, there has not previously been a need to apply S to row crops within the NGP. However, not unlike N, if supply of soil $\mathrm{S}$ is not keeping up with plant demands there is a likelihood of deficiency and reduction in yield potential.

It is difficult to accurately measure soil $S$ levels because of highly variable soil test results [2] [19] [22] [23]. Kaiser and Lamb [22] determined that fertilizing soybean in Minnesota with S increased plant growth but not yield, except under low S plant availability [23]. However, trials conducted in 2011 and 2012 across various soil types in northern Minnesota reported a soybean yield increase of approximately $134 \mathrm{~kg} \cdot \mathrm{ha}^{-1}$ across S fertilizer rates of 0 to $56 \mathrm{~kg} \cdot S \cdot \mathrm{ha}^{-1}$ [24]. In Tennessee 11, 23, and $34 \mathrm{~kg} \cdot \mathrm{S} \cdot \mathrm{ha}^{-1}$ as AMS, were applied to soybean in an S deficient soil. Soybean seed S content was significantly increased, but not yield [25].

The application of gypsum in Ohio, (where $\mathrm{S}$ deposition has greatly declined since 1990) at rates of $16 \mathrm{~kg} \mathrm{~S}$ and $67 \mathrm{~kg} \cdot \mathrm{S} \cdot \mathrm{ha}^{-1}$, increased soybean yield by $4.8 \%$ and $11.6 \%$, respectively [20]. In India, application of gypsum alone, up to a rate of $40 \mathrm{~kg} \cdot \mathrm{S} \cdot \mathrm{ha}^{-1} 30 \mathrm{~d}$ after planting, increased the yield of soybean nearly $40 \%$, and yield continued to increase with the additional application of farm yard manure which, also contains $\mathrm{N}$ [26]

In other legumes, additions of $\mathrm{S}$ have shown positive responses to nodulation. Fertilizing with $S$ increased average nodule number and average nodule mass of white clover (Trifolium repens $\mathrm{L}$.) compared to white clover grown under S deficient conditions [27]. Application of $\mathrm{S}$ in the form of $\mathrm{CaSO}_{4}$ significantly increased dry mass (10\%) and nodule number (45\%) of garden pea (Pisum sativum L.) [28]. Ammonium sulfate depressed nodulation but addition of $S$ increased nodules plant ${ }^{-1}$ by $36 \%$ in soybean [29]. Although S fertilization may not be necessary for all soils, its need has been well documented and thus warrants more investigation for some regions.

Given the dominance of soybeans within farmers' rotations in Minnesota and the NGP and the genetic potential for higher yields, the objectives of this study were to determine the effect of $\mathrm{N}$ and $\mathrm{S}$ fertilization on soybean nodulation, nodule size, above ground plant mass, and root growth. No previous regional research has evaluated a potential interaction of fertilizer $\mathrm{N}$ and $\mathrm{S}$ on nodulation and plant mass. The null hypothesis for this study is that the application of $\mathrm{N}$ and $\mathrm{S}$ do not influence these metrics.

\section{Materials and Methods}

There were five-site years each for 2015 and 2016, all of which were within southeastern North Dakota. Sites included the North Dakota State University (NDSU) experiment station located in Fargo, with 2 experiments (under controlled tile drainage and naturally drained conditions) each, in 2015 and 2016; near Moore- 
ton, Lisbon and Gwinner in 2015; and near Lisbon, Gwinner, and Hope in 2016. Except the Fargo location, all experiments were conducted on farmers' fields. Sites were selected to represent a normal farm condition and none of the experiments had known $\mathrm{N}$ or S limitations.

Each experiment at the Fargo site had four replications and each other site had two replications, each year. The site, soil and previous crop information are provided in Table 1 . Soil samples were taken prior to the fertilizer application, and analyzed at the NDSU Soil Testing Laboratory (Table 2).

At each site, there were two cultivar by six fertilizer treatments observation

Table 1. Site (and GPS coordinate), soil series, taxonomy, and previous crop at Fargo, Lisbon, Mooreton, Gwinner and Hope, ND, in 2015 and 2016.

\begin{tabular}{|c|c|c|c|}
\hline Site/GPS & Soil Series ${ }^{a}$ & Soil Taxonomy ${ }^{a}$ & Prev. Crop ${ }^{b}$ \\
\hline Fargo & Fargo-Ryan & Fine, smectitic, frigid Typic Epiaquerts & Wheat/Corn \\
\hline \multicolumn{2}{|c|}{$46.932 \mathrm{~N}, 96.859 \mathrm{~W}$} & Fine, smectitic, frigid Typic Natraquerts & \\
\hline Lisbon & Barnes-Svea & Fine-loamy, mixed, superactive, frigid Calcic Hapludolls & Corn \\
\hline \multicolumn{2}{|c|}{$46.443 \mathrm{~N}, 97.834 \mathrm{~W}$} & Fine-loamy, mixed, superactive, frigid Pachic Hapludolls & \\
\hline Mooreton & Fargo-Enloe & Fine, smectitic, frigid Typic Epiaquerts & Sugarbeet \\
\hline \multicolumn{2}{|c|}{$46.261 \mathrm{~N}, 96.816 \mathrm{~W}$} & Fine, smectitic, frigid Argiaquic Argialbolls & \\
\hline Gwinner & Hamerly-Tonka & Fine-loamy, mixed, superactive, frigid Aeric Calciaquolls & Corn \\
\hline \multicolumn{2}{|c|}{$46.212 \mathrm{~N}, 97.654 \mathrm{~W}$} & Fine, smectitic, frigid Argiaquic Argialbolls & \\
\hline Hope & Brantford & Fine-loamy over sandy or sandy-skeletal, mixed, & Soybean \\
\hline \multicolumn{2}{|c|}{$47.440 \mathrm{~N}, 97.653 \mathrm{~W}$} & Superactive, frigid Typic Hapludolls & \\
\hline
\end{tabular}

asoil data obtained from USDA [30]. ' Prev. Crop = Previous Crop. Fargo, in 2014 wheat [Triticum aestivum (L.) emend. Thell.] and in 2015 corn (Zea mays L.), and in Mooreton 2014 sugarbeet (Beta vulgaris L.).

Table 2. Soil test results at all site-years in 2015 and 2016.

\begin{tabular}{|c|c|c|c|c|c|c|c|c|}
\hline \multirow{2}{*}{ Year } & \multirow{2}{*}{ Location } & \multirow{2}{*}{$\begin{array}{c}\text { Depth } \\
\mathrm{cm}\end{array}$} & \multirow{2}{*}{$\begin{array}{l}\mathrm{NO}_{3}-\mathrm{N} \\
\mathrm{kg} \cdot \mathrm{ha}^{-1}\end{array}$} & $\mathrm{P}$ & $\mathrm{K}$ & \multirow{2}{*}{$\begin{array}{c}\mathrm{SO}_{4}-\mathrm{S} \\
\mathrm{kg} \cdot \mathrm{ha}^{-1}\end{array}$} & \multirow[t]{2}{*}{$\mathrm{pH}$} & \multirow{2}{*}{$\begin{array}{c}\mathrm{OM} \\
\%\end{array}$} \\
\hline & & & & \multicolumn{2}{|c|}{$\mathrm{mg} \cdot \mathrm{kg}^{-1}$} & & & \\
\hline \multirow[t]{5}{*}{2015} & Lisbon & $0-30$ & 16 & 6 & 180 & 511 & 7.4 & 3.2 \\
\hline & Mooreton & $0-30$ & 9 & 3 & 240 & 25 & 7.8 & 4.0 \\
\hline & Gwinner & $0-30$ & 4 & 6 & 180 & 34 & 7.5 & 4.3 \\
\hline & Fargo NAD ${ }^{a}$ & $0-30$ & 17 & 12 & 425 & 67 & 8.1 & 4.7 \\
\hline & Fargo CTD ${ }^{\mathrm{a}}$ & $0-30$ & 19 & 14 & 428 & 53 & 8.0 & 4.8 \\
\hline \multirow[t]{5}{*}{2016} & Lisbon & $0-30$ & 40 & 11 & 146 & 20 & 7.0 & 4.0 \\
\hline & Gwinner & $0-30$ & 53 & 12 & 174 & 258 & 7.6 & 4.6 \\
\hline & Hope & $0-30$ & 29 & 12 & 126 & 13 & 6.8 & 2.9 \\
\hline & Fargo NAD & $0-31$ & 36 & 10 & 473 & 83 & 7.7 & 5.6 \\
\hline & Fargo CTD & $0-32$ & 38 & 13 & 416 & 61 & 7.6 & 5.9 \\
\hline
\end{tabular}

${ }^{\mathrm{a}} \mathrm{OM}=$ Organic matter. $\mathrm{NAD}=$ Naturally drained, $\mathrm{CTD}=$ Controlled tile drained. 
plots. These plots were used for destructive sampling and collecting data on nodule number and size, as well as above ground plant and root biomass. No yield data was obtained from observational plots. Each whole plot $(1.5 \times 14.2 \mathrm{~m})$ was planted with one cultivar and split into six subplots with fertilizer treatment (1.5 $\times 1.8 \mathrm{~m}$ ), with $0.45 \mathrm{~m}$ between subplots and $1 \mathrm{~m}$ border at each end of the main plot.

Two indeterminate soybean cultivars were used: Peterson Farm Seed 15R07 (PFS 15R07) and Proseed 30-80 (PS 30-80). Cultivar PFS15R07 is a 0.7 maturity group, bushy plant type with medium height and has a 1.8 iron deficiency tolerance score $(1=$ green, $5=$ yellow). Cultivar PS $30-80$ is a 0.8 maturity group, erect plant type with medium-tall plant height and has a 2.4 iron deficiency tolerance score (less tolerant than PFS 15R07). Both cultivars' seeds were treated with ApronMaxx RTA fungicide (Mefenoxam [(R)-2-[(2, 6-dimethylphenyl) methoxyacetylamino]propionic acid methyl ester] and Fludioxonil [4-(2,2-Difluoro1,3-benzodioxol-4-yl)-1H-pyrrole-3-carbonitrile]) (Syngenta Crop Protection, LLC, Basel, Switzerland) prior to planting at a rate of $3.26 \mathrm{~mL} \cdot \mathrm{kg}^{-1}$ of seed in order to limit early disease pressure. Just before planting seed was inoculated, as many growers in Minnesota and the GNP do, with Vault SP (Bradyrhizobium japonicum) inoculum (BASF, Ludwigshafen, Germany) at a rate of $1.8 \mathrm{~g}$ Vault per kg soybean seed, the day of planting. The NDSU recommended soybean live seeding rate of 370,500 seeds $\cdot \mathrm{ha}^{-1}$ was used. Soybean was planted with a Hege 1000, 4-row no-till planter (Hege Company, Waldenberg, Germany) with 35.6 $\mathrm{cm}$ row spacing. Seeds were sown to a depth of approximately $3 \mathrm{~cm}$.

Each subplot received different rates of $\mathrm{N}$ and $\mathrm{S}$ (Table 3). Nitrogen was applied in the form of urea (46-0-0) and $S$ was applied in the form of gypsum (0-0-0-17) (SuperCal $\mathrm{SO}_{4}$ pelletized agricultural gypsum, Calcium Products, Inc., Ames, IA). Treatments were randomized and applied shortly after VE (emergence, cotyledons above the soil surface) [9] by using a hoe to create a small furrow approximately 2.5 to $3.5 \mathrm{~cm}$ deep next to each plant row and applying fertilizer to the furrow by hand and then covering the furrow with soil.

Weeds were controlled using Roundup WeatherMAX (i.e. 48.8\% glyphosate, $\mathrm{N}$ (phosphonomethyl) glycine, in the form of its potassium salt) (Monsanto Co., St. Louis, MO). Insect pressure was monitored throughout the season and foliar

Table 3. Fertilizer treatments applied to observational plots.

\begin{tabular}{ccc}
\hline Fertilizer & $\mathrm{kg} \cdot \mathrm{N} \cdot \mathrm{ha}^{-1}$ & $\mathrm{~kg} \cdot \mathrm{S} \cdot \mathrm{ha}^{-1}$ \\
\hline Check & 0 & 0 \\
Urea & 140 & 0 \\
Urea & 280 & 0 \\
Urea + gypsum & 140 & 112 \\
Urea + gypsum & 280 & 112 \\
Gypsum & 0 & 112 \\
\hline
\end{tabular}


insecticide was applied as needed.

Plants from $1 \mathrm{~m}$ of one of the inner two rows in each sub-plot were removed using a shovel. The number of plants taken varied between eight and twenty-two, depending on the plant density of the randomly selected area. The roots of each plant were rinsed in a bucket with water to remove soil particles. Nodules on each plant were counted and rated for size. The nodule size on each plant was rated in percentages of small $(<1 \mathrm{~mm})$, medium $(1-4 \mathrm{~mm})$, and large $(>4 \mathrm{~mm})$. Size ratings and nodule counts were averaged over observed plants. Plant samples from plots were collected in cloth bags and dried for $10 \mathrm{~d}$ at approximately $50^{\circ} \mathrm{C}$.

After drying, the samples were weighed. The roots were then removed from the samples, and the samples were reweighed without roots. Average total plant mass, shoot mass, and root mass per plant were determined. This process was done at the vegetative stage, approximately V4, and again at the R4 [9] (full pod) stage, using $1 \mathrm{~m}$ of the not yet sampled inside row.

The V4 observation timing was selected to represent nodulation at the vegetative stage (V4) when the plants transition to the reproductive phase. The first root dig took place about one week before the first flowers (R1) appeared. The second root dig was at $\mathrm{R} 4$ when the pods were formed, and around the time of maximum $\mathrm{N}$ fixation as reports indicate that $\mathrm{N}$ fixation starts to reduce between the R5 and R7 stages [5].

Dates of field operation and measurement are provided in Table 4. Statistical analysis was conducted using standard procedures according to Carmer et al. [31] for a randomized complete block design with a two-factor factorial arrangement within a split plot, with cultivar being the main plot. All dependent variables were analyzed with a mixed model (PROC MIXED) on SAS 9.3 (SAS

Table 4. Dates of important measurements and field operations at Fargo, Lisbon, Mooreton, Gwinner, and Hope, ND, in 2015 and 2016.

\begin{tabular}{|c|c|c|c|c|c|}
\hline \multirow{2}{*}{ Measurement/Operation } & Fargo & Lisbon & Mooreton & Gwinner & Hope \\
\hline & \multicolumn{5}{|c|}{ Date } \\
\hline & \multicolumn{5}{|c|}{2015} \\
\hline Planting & 4 May & 5 May & 5 May & 5 May & - \\
\hline Fertilize & 5 June & 4 June & 4 June & 4 June & - \\
\hline First root dig & 1 July & 2 July & 2 July & 2 July & - \\
\hline \multirow[t]{2}{*}{ Second root dig } & 29 July & 28 July & 28 July & 28 July & - \\
\hline & \multicolumn{5}{|c|}{2016} \\
\hline Planting & 6 May & 12 May & - & 9 May & 16 May \\
\hline Fertilize & 1 June & 2 June & - & 2 June & 3 June \\
\hline First root dig & $7 / 8 \mathrm{July}^{\dagger}$ & 29 June & - & 29 June & 30 June \\
\hline Second root dig & 1 Aug & 29 July & - & 29 July & 29 July \\
\hline
\end{tabular}


Institute Inc., Cary, NC). Cultivar and fertilizer treatment were considered fixed variables, replicates and site-year were considered random variables. The data were analyzed for each site in 2015 and 2016 separately. After confirming homogeneity of variance according to Bartlett's Chi-Square test, data was then combined and analyzed over all site-years of the study. Treatment means were separated using Fisher's protected least significant difference (LSD) at the 95\% level of confidence $(\alpha=0.05)$. Weather data for the Fargo location was collected from the North Dakota Agricultural Weather Network (NDAWN) station in Fargo, ND. Weather data for the Lisbon, Mooreton, Gwinner, and Hope sites were collected from the NDAWN weather station located near Lisbon, Wahpeton, Oakes, and Finley, ND, respectively.

\section{Results and Discussion}

\subsection{Weather}

In 2015, May precipitation at all locations was 2 to 2.8 times more compared with the long-term normal precipitation. However, precipitation in June through September tended to be below normal, which greatly reduced the cumulative seasonal precipitation and was below the long-term average in Lisbon, Mooreton, and Gwinner (Table 5). The seasonal precipitation in 2016 was near average in Fargo and Lisbon and slightly above average for Gwinner and Hope. The growing conditions in 2016 were more conducive to soybean growth and the highest yielding environments in the study were Lisbon and Hope in 2016 with average yields of 4.49 and $4.15 \mathrm{Mg} \cdot \mathrm{ha}^{-1}$, respectively, based on yield studies adjacent to this fertilizer study.

\subsection{Nodulation}

Levels of significance for cultivar, N, S and interactions for the first (V4) and second (R4) nodulation observations are presented in Table 6 and Table 7, respectively.

Table 5. Precipitation for each month during the growing season Fargo, Lisbon, Mooreton, Gwinner and Hope 2015 and 2016.

\begin{tabular}{|c|c|c|c|c|c|c|c|c|c|c|c|c|c|}
\hline & \multicolumn{13}{|c|}{ Precipitation } \\
\hline & $\begin{array}{c}\text { Fargo } \\
2015\end{array}$ & $\begin{array}{c}\text { Fargo } \\
2016\end{array}$ & $\begin{array}{c}\text { Fargo } \\
\text { Norm. }\end{array}$ & $\begin{array}{c}\text { Lisbon } \\
2015\end{array}$ & $\begin{array}{c}\text { Lisbon } \\
2016\end{array}$ & $\begin{array}{l}\text { Lisbon } \\
\text { Norm. }\end{array}$ & $\begin{array}{c}\text { Mooreton } \\
2015\end{array}$ & $\begin{array}{c}\text { Mooreton } \\
\text { Norm. }\end{array}$ & $\begin{array}{c}\text { Gwinner } \\
2015\end{array}$ & $\begin{array}{c}\text { Gwinner } \\
2016\end{array}$ & $\begin{array}{c}\text { Gwinner } \\
\text { Norm. }\end{array}$ & $\begin{array}{c}\text { Hope } \\
2016\end{array}$ & $\begin{array}{l}\text { Hope } \\
\text { Norm. }\end{array}$ \\
\hline & \multicolumn{13}{|c|}{$\mathrm{mm}$} \\
\hline May & 200 & 33 & 71 & 154 & 67 & 75 & 153 & 81 & 152 & 51 & 75 & 70 & 68 \\
\hline July & 71 & 132 & 71 & 35 & 81 & 80 & 70 & 81 & 20 & 140 & 82 & 112 & 79 \\
\hline Aug & 54 & 48 & 65 & 43 & 128 & 54 & 26 & 62 & 33 & 129 & 60 & 54 & 69 \\
\hline Sept & 41 & 80 & 65 & 7 & 44 & 65 & 11 & 74 & 20 & 26 & 64 & 73 & 46 \\
\hline Total & 430 & 362 & 371 & 330 & 359 & 354 & 322 & 381 & 306 & 412 & 377 & 402 & 357 \\
\hline
\end{tabular}

${ }^{a}$ Norm. is normal, which represents a 30-yr average from 1981-2010. Data obtained from North Dakota Agricultural Weather Network. 
Table 6. Significance levels for the ANOVA for root characteristics at V4, combined across all site-years.

\begin{tabular}{|c|c|c|c|c|c|c|c|c|}
\hline $\mathrm{SOV}^{\mathrm{a}}$ & df & AN & $\mathrm{Sm}$ & $\mathbf{M}$ & $\mathrm{L}$ & PM & SM & RM \\
\hline Site [Site-year] & 9 & & & & & & & \\
\hline Rep (Site) & 18 & & & & & & & \\
\hline CT [Cultivar] & 1 & $* * *$ & $\mathrm{~ns}$ & ns & ns & $\mathrm{ns}$ & $\mathrm{ns}$ & * \\
\hline CT by Site & 9 & & & & & & & \\
\hline $\mathrm{N}$ [Nitrogen] & 2 & $* * *$ & $* * *$ & ns & $* * *$ & ns & ns & $\mathrm{ns}$ \\
\hline CT by $\mathrm{N}$ & 2 & ns & $\mathrm{ns}$ & ns & ns & ns & ns & ns \\
\hline S [Sulfur] & 1 & ns & ns & ns & ns & ns & ns & ns \\
\hline CT by $S$ & 1 & * & ns & ns & ns & ns & ns & ns \\
\hline $\mathrm{N}$ by $\mathrm{S}$ & 2 & ns & $\mathrm{ns}$ & ns & ns & ns & ns & ns \\
\hline CT by $\mathrm{N}$ by $\mathrm{S}$ & 2 & $\mathrm{~ns}$ & $\mathrm{~ns}$ & ns & ns & ns & $\mathrm{ns}$ & ns \\
\hline Residual Error & 180 & & & & & & & \\
\hline
\end{tabular}

$\mathrm{ns},{ }^{*},{ }^{* *},{ }^{* *}=$ not significant, significant at $(\mathrm{p} \leq 0.05),(\mathrm{p} \leq 0.01)$, and $(\mathrm{p} \leq 0.001)$, respectively. SOV $\mathrm{S}^{\mathrm{a}}=$ source of variation, $\mathrm{df}=$ degrees of freedom, $\mathrm{AN}=$ average nodules per plant, $\mathrm{Sm}=$ average small nodules per plant, $\mathrm{M}=$ average medium nodules per plant, $\mathrm{L}=$ average large nodules per plant, $\mathrm{PM}=$ average plant mass, $\mathrm{SM}=$ average shoot mass per pant, $\mathrm{RM}=$ average root mass per plant.

Table 7. Significance levels for the ANOVA for root characteristics at R4, combined across all site-years.

\begin{tabular}{|c|c|c|c|c|c|c|c|c|}
\hline $\mathrm{SOV}^{\mathrm{a}}$ & $\mathrm{DF}$ & AN & SM & $\mathbf{M}$ & L & PM & SM & $\mathrm{RM}$ \\
\hline Site [Site-year] & 9 & & & & & & & \\
\hline Rep (Site) & 18 & & & & & & & \\
\hline CT [Cultivar] & 1 & ns & ns & * & * & ns & ns & ns \\
\hline CT by Site & 9 & & & & & & & \\
\hline $\mathrm{N}$ [Nitrogen] & 2 & $* * *$ & $* * *$ & ns & $* * *$ & ns & ns & ns \\
\hline CT by $\mathrm{N}$ & 2 & ns & ns & * & ns & * & * & * \\
\hline S [Sulfur] & 1 & ns & ns & * & $\mathrm{ns}$ & ns & ns & ns \\
\hline CT by S & 1 & ns & * & ns & * & ns & ns & ns \\
\hline $\mathrm{N}$ by $\mathrm{S}$ & 2 & ns & ns & ns & ns & ns & ns & ns \\
\hline CT by $\mathrm{N}$ by $\mathrm{S}$ & 2 & ns & ns & ns & ns & ns & ns & $\mathrm{ns}$ \\
\hline Residual Error & 180 & & & & & & & \\
\hline
\end{tabular}

$\mathrm{ns},{ }^{*},{ }^{* *},{ }^{* *}=$ not significant, significant at $(\mathrm{p} \leq 0.05),(\mathrm{p} \leq 0.01)$, and $(\mathrm{p} \leq 0.001)$, respectively. SOV $\mathrm{S}^{\mathrm{a}}=$ source of variation, $\mathrm{df}=$ degrees of freedom, $\mathrm{AN}=$ average nodules per plant, $\mathrm{Sm}=$ average small nodules per plant, $\mathrm{M}=$ average medium nodules per plant, $\mathrm{L}=$ average large nodules per plant, $\mathrm{PM}=$ average plant mass, $\mathrm{SM}=$ average shoot mass per plant, $\mathrm{RM}=$ average root mass per plant.

Nodule count per plant during R4, at each site year, was higher than at V4, except at 2016 Lisbon and 2015 Mooreton. Across all site years, the number of nodules at R4 was higher than at V4. The average nodule number per plant was highly variable between site-years (Figure 1). In addition, the percent increase in 
average nodule number between V4 and R4 was different between site-years. In 2016, the average nodule number per plant increased 5\% and 73\% in Lisbon and Hope, respectively (Figure 1). Possible explanations for differential environmental response include factors such soil type, previous crop (Table 1), precipitation (Table 5), and level of soil $\mathrm{N}$ at the start of the experiment (Table 2).

\subsection{Cultivar}

Average nodule number per plant was significantly different at the V4 stage between cultivars. However, by the R4 stage cultivar had no significant impact on average nodule number per plant (Table 8). A significant difference in root mass between cultivars was also observed at the V4 growth stage, but evened out by the R4 growth stage (Table 8). Cultivars differed in average percent medium and large nodules at the R4 stage. PFS $15 \mathrm{R} 07$ had an average of 5.2\% more large nodules per plant than PS $30-80$ at the R4 stage (Table 9).

\subsection{Nitrogen}

As the $\mathrm{N}$ rate increased at both observed growth stages, average nodule number per plant decreased and average nodule size decreased (Table 10). The average

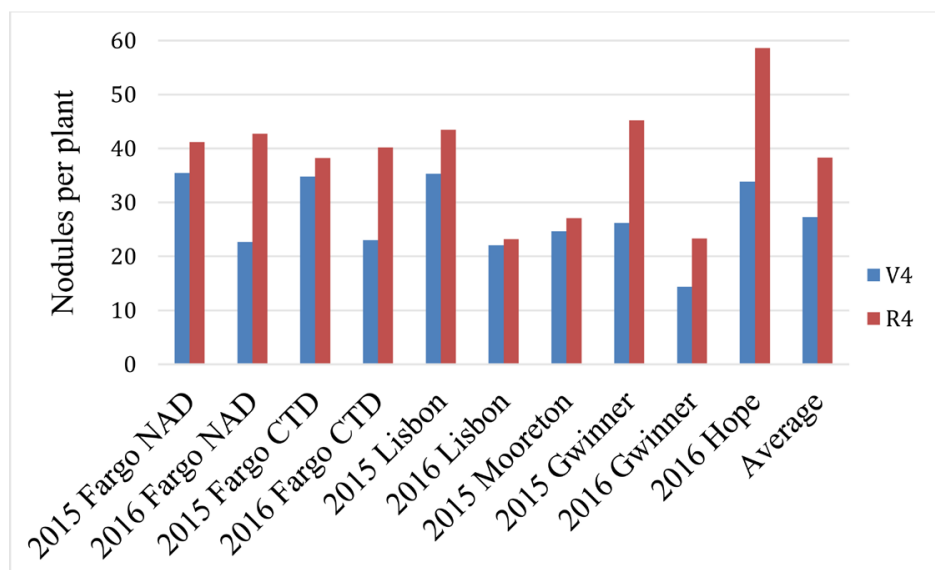

All comparisons of nodules per plant at V4 and R4 at each site-year are significantly different at ( $\mathrm{p} \leq$ 0.05), including the average, except at 2016 Lisbon and 2015 Mooreton.

Figure 1. Average nodules per plant at V4 and R4 in each site-year.

Table 8. Cultivar effect on average nodule number and root mass per plant across all site-years at V4 and R4.

\begin{tabular}{ccccc}
\hline & \multicolumn{2}{c}{ AN $^{\mathrm{a}}$} & \multicolumn{2}{c}{$\mathrm{RM}$} \\
\cline { 2 - 5 } Cultivar & $\mathrm{V} 4$ & $\mathrm{R} 4$ & $\mathrm{~V} 4$ & $\mathrm{R} 4$ \\
\cline { 2 - 5 } & \multicolumn{2}{c}{ nodule.plant $^{-1}$} & \multicolumn{2}{c}{$\mathbf{g}$} \\
\hline PS 30 - 80 & $30.3 \mathrm{a}$ & $39.8 \mathrm{a}$ & $0.49 \mathrm{a}$ & $1.68 \mathrm{a}$ \\
PFS 15R07 & $24.4 \mathrm{~b}$ & $36.9 \mathrm{a}$ & $0.47 \mathrm{~b}$ & $1.74 \mathrm{a}$ \\
\hline
\end{tabular}

Means in a column followed by a different letter are significantly different at $(\mathrm{p} \leq 0.05)$. ${ }^{\mathrm{a}} \mathrm{AN}=$ average nodule number, $\mathrm{RM}=$ average root mass per plant. 
Table 9. Cultivar effect on percent small, medium, and large nodules per plant across all site-years at V4 and R4.

\begin{tabular}{ccccccc}
\hline & \multicolumn{2}{c}{$\mathrm{Sm}^{\mathrm{a}}$} & \multicolumn{3}{c}{ M } & \multicolumn{2}{c}{$\mathrm{L}$} \\
\cline { 2 - 7 } Cultivar & V4 & R4 & V4 & R4 & V4 & R4 \\
\cline { 2 - 7 } & & & \multicolumn{2}{c}{$\%$} \\
\hline PS 30 - 80 & $29.7 \mathrm{a}$ & $27.6 \mathrm{a}$ & $51.1 \mathrm{a}$ & $60.6 \mathrm{a}$ & $19.5 \mathrm{a}$ & $11.8 \mathrm{a}$ \\
PFS 15R07 & $28.0 \mathrm{a}$ & $26.2 \mathrm{a}$ & $49.6 \mathrm{a}$ & $57.1 \mathrm{~b}$ & $22.6 \mathrm{a}$ & $17.0 \mathrm{~b}$ \\
\hline
\end{tabular}

Means in a column followed by a different letter are significantly different at $(\mathrm{p} \leq 0.05)$. ${ }^{\mathrm{a}} \mathrm{Sm}=$ average small $(<1 \mathrm{~mm})$ nodules per plant, $\mathrm{M}=$ average medium $(1-4 \mathrm{~mm})$ nodules per plant, $\mathrm{L}=$ average large $(>4 \mathrm{~mm})$ nodules per plant.

Table 10. Nitrogen effect on average nodules per plant, and percent small, medium, and large nodules per plant across all site-years at V4 and R4.

\begin{tabular}{|c|c|c|c|c|c|c|c|c|}
\hline \multirow{3}{*}{$\begin{array}{c}\text { Rate } \\
\mathrm{kg} \cdot \mathrm{N} \cdot \mathrm{ha}^{-1}\end{array}$} & \multicolumn{2}{|c|}{$\mathrm{AN}^{\mathrm{a}}$} & \multicolumn{2}{|c|}{$\mathrm{Sm}$} & \multicolumn{2}{|c|}{$\mathbf{M}$} & \multicolumn{2}{|c|}{$\mathbf{L}$} \\
\hline & V4 & R4 & V4 & R4 & V4 & R4 & $\mathrm{V} 4$ & R4 \\
\hline & \multicolumn{2}{|c|}{ Nodule.plant ${ }^{-1}$} & \multicolumn{6}{|c|}{$\%$} \\
\hline 0 & $31.8 \mathrm{a}$ & $44.3 \mathrm{a}$ & $19.8 \mathrm{~b}$ & $22.0 \mathrm{c}$ & $47.9 \mathrm{a}$ & $56.7 \mathrm{a}$ & $32.4 \mathrm{a}$ & $21.4 \mathrm{a}$ \\
\hline 140 & $26.5 b$ & $37.3 b$ & $30.5 a$ & $26.8 \mathrm{~b}$ & $51.9 \mathrm{a}$ & $59.9 \mathrm{a}$ & $17.9 \mathrm{~b}$ & $13.7 \mathrm{~b}$ \\
\hline 280 & $23.7 \mathrm{~b}$ & $33.5 \mathrm{~b}$ & $36.3 a$ & $32.0 \mathrm{a}$ & $51.1 \mathrm{a}$ & $60.0 \mathrm{a}$ & $12.8 \mathrm{~b}$ & $8.0 \mathrm{c}$ \\
\hline
\end{tabular}

Means in a column followed by a different letter are significantly different at $(\mathrm{p} \leq 0.05) .{ }^{\mathrm{a}} \mathrm{AN}=$ average nodule number, $\mathrm{Sm}=$ average number of small $(<1 \mathrm{~mm})$ nodules per plant, $\mathrm{M}=$ average medium $(1-4 \mathrm{~mm})$ nodules per plant, $\mathrm{L}=$ average number of large $(>4 \mathrm{~mm})$ nodules per plant.

nodule number per plant was significantly lower than the control for the 140 and $280 \mathrm{Kg} \cdot \mathrm{ha}^{-1} \mathrm{~N}$ rate, at both observation stages. The average number of nodules per plant was not significantly different between the rates of $140 \mathrm{~kg}$ and 280 $\mathrm{kg} \cdot \mathrm{N} \cdot \mathrm{ha} \mathrm{a}^{-1}$ at either stage.

As $\mathrm{N}$ rate increased, the average percent of small nodules per plant increased at both stages and the average percent of large nodules decreased. Results agree with other researchers [25] [32] [33] [34] who indicated a strong inhibition of nodulation and $\mathrm{N}_{2}$ fixation activity under high nitrate conditions. The results of this study confirm those reported by Hungria et al. [35] and Mendes et al. [36] who conclude that $\mathrm{N}$ fertilization at rates of 30 to $400 \mathrm{~kg} \cdot \mathrm{N} \cdot \mathrm{ha}^{-1}$ decreased nodulation and the contribution of biological $\mathrm{N}$ fixation. However, Mendes et al. [36] reported that average nodule number was 50\% lower for plants treated with 40 $\mathrm{kg} \cdot \mathrm{N} \cdot \mathrm{ha}^{-1}$ compared to the control $15 \mathrm{~d}$ after emergence, but these significant differences in average nodule number per plant had disappeared by the R1 stage. The significant difference between average nodule number at R4 with and without $\mathrm{N}$ fertilizer reported in this study could be attributed to the higher rates of $\mathrm{N}$ fertilizer used compared with Mendes et al. [36].

Our results also agree with those of Salvagiotti et al. [37], who showed a negative $\mathrm{N}$ fixation response as $\mathrm{N}$ fertilizer was added to the soil surface or incorporated in the topmost layers. Specifically, nitrate has been shown to decrease no- 
dule number, nodule mass, and $\mathrm{N}$ fixation activity, and accelerate nodule senescence. Results of this study show the same trend of decreased average nodule number and decreased average nodule mass. Saito et al. [38] concluded that rapid inhibition of nodule activity was attributed to a decrease in transport of photosynthate to nodules from the shoot. Ohyama et al. [39] reported that soybean nodule growth completely stopped after $1 \mathrm{~d}$ of application of $0.005 \mathrm{~mol} \cdot \mathrm{L}^{-1}$ $\mathrm{NO}_{3}^{-}$solution. Many hypotheses have been proposed as the cause of nodulation inhibition by nitrate including carbohydrate-deprivation in nodules [32], feedback inhibition by a product of nitrate metabolism [40] [41], and decreased oxygen diffusion into nodules [42] [43].

Nitrogen application was expected to increase the average plant, shoot and root mass of the soybean plant. However in this study, $\mathrm{N}$ rate of 0,140 and 280 $\mathrm{kg} \cdot \mathrm{ha}^{-1}$ did not significantly influence plant mass. Averaged across $\mathrm{N}$ rates total plant mass was 2.26 and $11.36 \mathrm{~g}$ per plant at V4 and R4, respectively. Shoot mass, average across $\mathrm{N}$ rates was 1.77 and $9.65 \mathrm{~g}$ per plant at $\mathrm{V} 4$ and $\mathrm{R} 4$, respectively, and root mass, average across $\mathrm{N}$ rates was 0.49 and 1.71 .g per plant at $\mathrm{V} 4$ and $\mathrm{R} 4$, respectively.

\subsection{Sulfur}

At the V4 and R4 growth stage, $\mathrm{S}$ had no significant effect on nodules per plant, percent small or large nodules. However, at the R4 growth stage S significantly influenced medium nodule size with 57.2 and $60.5 \%$ of the total nodules being medium sized for the 0 and $112 \mathrm{~kg} \cdot \mathrm{S} \cdot \mathrm{ha}{ }^{-1}$, respectively. Results reported by Varin et al. [27] indicated that $S$ significantly increased nodule size of white clover. However, in our study the average percent of small and large sized nodules per plant did not change in response to $S$ application.

\subsection{Cultivar by Sulfur}

The Anova showed a cultivar by S interaction at the V4 growth stage for the number of nodules per plant (Table 6). The cultivar PS $30-80$ had 30.5 and 30.1 nodules with 0 and $112 \mathrm{~kg} \cdot \mathrm{S} \cdot \mathrm{ha}^{-1}$, respectively (not significantly different). The cultivar PFS 15R07 had significantly lower number of nodules, 23.5 and 25.2 with 0 and $112 \mathrm{~kg} \cdot S \cdot h \mathrm{~h}^{-1}$, respectively, compared with PS 30 - 80 but nodules per plant for PS 30 - 80 were not different between the two rates. The significant difference in the interaction may be the result of a difference in magnitude between cultivars and not a true interaction.

For PS 30 - 80 the average percent large nodules per plant increased when 112 $\mathrm{kg} \cdot \mathrm{S} \cdot \mathrm{ha}^{-1}$ was applied compared with $0 \mathrm{~kg} \cdot \mathrm{S} \cdot \mathrm{ha}^{-1}$. Conversely, the average large nodules per plant decreased compared to the control for PFS 15R07 when 112 $\mathrm{kg} \cdot \mathrm{S} \cdot \mathrm{ha}^{-1}$ was applied (data not presented).

\subsection{Nitrogen by Sulfur Interaction}

The experiment was set up as a factorial to explore the interaction of $\mathrm{N}$ and $\mathrm{S}$. 
However, there were no significant differences for the interaction at the V4 or R4 growth stages for nodules per plant, small, medium or large nodules per plant, plant mass, shoot mass, or root mass per plant (Table 6 and Table 7).

\section{Conclusions}

Cultivar differences existed between average nodule numbers per plant at the V4 stage. PS 30 - 80 averaged 30.3 nodules per plant while PFS 15R07 averaged 24.4 nodules per plant. Root mass also differed between cultivars at the R4 stage. The average root mass of PS 30-80 and PFS 15R07 was $0.49 \mathrm{~g}$ per root and $0.47 \mathrm{~g}$ per root, respectively, at R4. A relationship was expected between average nodule number and root mass. Overall there was no linear regression relationship at the V4 observation between average nodules per plant and average root mass per plant $\left(r^{2}=0.0055 ; \mathrm{p}=0.175\right)$. There was a weak positive linear regression relationship at the R4 observation between average nodules per plant and average root mass per plant $\left(\mathrm{r}^{2}=0.032 ; \mathrm{p}=0.001\right)$.

Nitrogen influenced a number of plant characteristics related to nodulation including average nodules per plant and nodule size. The average number of nodules per plant was significantly lower than the control at both growth stages when plants were treated with 140 and $280 \mathrm{~kg} \cdot \mathrm{N} \cdot \mathrm{ha}^{-1}$, but the average number of nodules per plant was not different between the 140 and $280 \mathrm{~kg} \cdot \mathrm{N} \cdot \mathrm{ha}^{-1}$ treatments at either stage. The general trend indicated that average nodule size became smaller as $\mathrm{N}$ application rate increased. At R4, the interaction of cultivar and $\mathrm{N}$ influenced the average percent medium nodules per plant, average plant mass and average shoot mass. Cultivars responded differently to $\mathrm{N}$ rate with regard to plant mass and shoot mass. The interaction of cultivar and $\mathrm{N}$ for average percent medium nodules per plant indicates that average percent medium nodules per plant of PFS 15R07 increased as N rate increased, while PS 30 - 80 initially increased but then decreased. However, the average percent medium nodules per plant of PFS 15R07 appeared to respond more to N than PS 30 - 80 . Overall, $\mathrm{N}$ fertilizer was a more dominant factor for influencing nodulation than $S$ fertilizer.

Sulfur influenced nodule size at the R4 stage. However, the relationship remains unclear and more research is necessary to establish how $\mathrm{S}$ influences nodule size. Additionally, the interaction of cultivar and $S$ influenced average nodule number at the V4 stage. The relationship indicates that the significance was due to a difference in magnitude for average nodules between cultivars and was not a true interaction. More research is needed to determine how $\mathrm{S}$ influences different soybean cultivars.

Nodulation and plant vegetation were more effected by fertilizer in early vegetative growth than reproductive growth, indicating that plant growth throughout the season made up for early differences between treatments and control. Soil types varied by site-year and likely influenced the results of the study; however, in this study no interaction between $\mathrm{N}$ and $\mathrm{S}$ was observed. 
Environments played a key role in response to treatments; however, the experimental sites in this study were not specifically selected for limiting $\mathrm{N}$ and $\mathrm{S}$ conditions. Future research should focus on understanding genotypic variations in response to $\mathrm{N}$ and $\mathrm{S}$ fertilizer, soil-specific response to $\mathrm{N}$ and $\mathrm{S}$ application, and different forms of $\mathrm{N}$ and $\mathrm{S}$ fertilizer at various application timings to maximize the sustainability of soybean production practices in Minnesota and the NGP States.

\section{Conflicts of Interest}

The authors declare no conflicts of interest regarding the publication of this paper.

\section{References}

[1] United States Department of Agriculture (USDA) (2020) National Agricultural Statistics Service, Quick Stats. https://quickstats.nass.usda.gov

[2] Franzen, D., Goos, R.J., Kandel, H., Augustin, C., Buetow, R., Teboh, J., Forster, S. and Endres, G. (2019) Soybean Soil Fertility. NDSU Ext. Serv. SF1164 (Revised). North Dakota Agric. Exp. Station, Fargo. https://www.ag.ndsu.edu/publications/crops/soybean-soil-fertility/sf1164.pdf

[3] Vitti, G. and Trevisan, W. (2000) Agricultural Management of Grain Legumes; Has It Led to An Increase in Nitrogen Fixation? Field Crops Research, 65, 165-181. https://doi.org/10.1016/S0378-4290(99)00085-4

[4] Lamond, R.E. and Wesley, T.L. (2001) In-Season Fertilization for High Yield Soybean Production. Better Crops, 85, 6-11.

[5] Ciampitti, I.A. and Salvagiotti, F. (2018) New Insights into Soybean Biological Nitrogen Fixation. Agronomy Journal, 110, 1185-1196. https://doi.org/10.2134/agronj2017.06.0348

[6] Santachiara, G., Salvagiotti, F. and Rotundo, J.L. (2019) Nutritional and Environmental Effects on Biological Nitrogen Fixation in Soybean: A Meta-Analysis. Field Crops Research, 240, 106-115. https://doi.org/10.1016/j.fcr.2019.05.006

[7] Ying, J.F., Herridge, D.F., Peoples, M.B. and Rerkasem, B. (1992) Effects of N Fertilization on $\mathrm{N}_{2}$ Fixation and $\mathrm{N}$ Balances of Soybean Grown after Lowland Rice. Plant and Soil, 147, 235-242. https://doi.org/10.1007/BF00029075

[8] Heatherly, L.G., Spurlock, S.R. and Reddy, K.N. (2003) Influence of Early-Season Nitrogen and Weed Management on Irrigated and Nonirrigated Glyphosate-Resistant and Susceptible Soybean. Agronomy Journal, 95, 446-453. https://doi.org/10.2134/agronj2003.4460

[9] Fehr, W.R., Caviness, C.E., Burmood, D.T. and Pennington, J.S. (1971) Stage of Development Descriptions for Soybeans, Glycine max (L.) Merrill. Crop Science, 11, 929-931. https://doi.org/10.2135/cropsci1971.0011183X001100060051x

[10] Starling, M.E., Wood, C.W. and Weaver, D.B. (1998) Starter Nitrogen and Growth Habit Effects on Late-Planted Soybean. Agronomy Journal, 90, 658-662. https://doi.org/10.2134/agronj1998.00021962009000050015x

[11] Bhangoo, M.S. and Albritton, D.J. (1976) Nodulating and Non-Nodulating Lee Soybean Isolines Reponse to Applied Nitrogen. Agronomy Journal, 68, 642-645. https://doi.org/10.2134/agronj1976.00021962006800040027x 
[12] Zapata, F., Danso, S.K.A., Hardarson, G. and Fried, M. (1987) Time Course of Nitrogen Fixation in Field-Grown Soybean Using Nitrogen-15 Methodology. Agronomy Journal, 79, 172-176. https://doi.org/10.2134/agronj1987.00021962007900010035x

[13] Beard, B.H. and Hoover, R.M. (1971) Effect of Nitrogen on Nodulation and Yield of Irrigated Soybeans. Agronomy Journal, 63, 815-816. https://doi.org/10.2134/agronj1971.00021962006300050051x

[14] Touchon, J.T. and Rickerl, D.H. (1986) Soybean Growth and Yield Responses to Starter Fertilizers. Soil Science Society of America Journal, 50, 234-237. https://doi.org/10.2136/sssaj1986.03615995005000010045x

[15] Scheerer, H.W. (2009) Sulfur in Soils. Journal of Plant Nutrition and Soil Science, 172, 326-335. https://doi.org/10.1002/jpln.200900037

[16] Shaver, T.M. (2014) Nutrient Management for Agronomic Crops. Pub. EC155. Univ. of Nebraska Ext., Lincoln. http://extensionpublications.unl.edu/assets/pdf/ec155.pdf

[17] Dick, W.A., Kost, D. and Chen, L. (2008) Availability of Sulfur to Crops from Soil and Other Sources. In: Jex, J., Ed., Sulfur. A Missing Link between Soils, Crops, and Nutrition, Agronomy Monograph 50, ASA, CSSA, and SSSA, Madison, 59-82. https://doi.org/10.2134/agronmonogr50.c5

[18] Baumgardner, R.E., Lavery, T.F., Rogers, C.M. and Isil, S.S. (2002) Estimates of the Atmospheric Deposition of Sulfur and Nitrogen Species: Clean Air Status and Trends Network, 1990-2000. Environmental Science and Technology, 36, 2614-2629. https://doi.org/10.1021/es011146g

[19] Franzen, D.W., Sharma, L.K., Bu, H. and Denton, A. (2016) Evidence for the Ability of Active Optical Sensors to Detect Sulfur Deficiency in Corn. Agronomy Journal, 108, 2158-2162. https://doi.org/10.2134/agronj2016.05.0287

[20] Chen, L., Dick, W.A. and Nelson, S. (2005) Flue Gas Desulfurization Products as Sulfur Sources for Alfalfa and Soybean. Agronomy Journal, 97, 265-271.

[21] DeSutter, T.M. and Cihacek, L. (2009) Potential Agricultural Uses of Flue Gas Desulfurization Gypsum in the Northern Great Plains. Agronomy Journal, 101, 817-825. https://doi.org/10.2134/agronj2008.0212Rx

[22] Kaiser, D.E. and Lamb, J.A. (2012) Nutrient Management: Fertilizing Soybean in Minnesota. Univ. of Minnesota Ext. AG-FO-03813-C. https://agprofessional.com/sites/default/files/FS-03813-A-1.pdf

[23] Kaiser, D.E. and Kim, K. (2013) Soybean Response to Sulfur Fertilizer Applied as a Broadcast or Starter Using Replicated Strip Trials. Agronomy Journal, 105, 1189-1198. https://doi.org/10.2134/agronj2013.0023

[24] Kruger, G., Willis, D., Torgerson, D. and Geiszler, M. (2014) To What Extent Does Sulfur and Ammonium Sulfate Impact Soybean Yields and When Does It Work Best? In: Minnesota Wheat Research and Promotion Council; On-Farm Research Trials 2014, Minnesota Wheat Growers, Red Lake Falls, MN, 31-34. https://mnwheat.org/wp-content/uploads/2018/03/2014-OFRN-Final.pdf

[25] Cannon, K.A. (2017). Optimizing Soybean (Glycine max L.) Yield with Nitrogen and Sulfur Applications. Master's Thesis, Univ. of Tennessee, Knoxville. https://trace.tennessee.edu/utk_gradthes/4729

[26] Ganeshamurthy, A.N. and Reddy, K.S. (2001) Effect of Integrated Use of Farmyard Manure and Sulphur in a Soybean and Wheat Cropping System on Nodulation/Dry Matter Production and Chlorophyll Content of Soybean on Swell-Shrink Soils in 
Central India. Journal of Agronomy and Crop Science, 185, 91-97.

https://doi.org/10.1046/j.1439-037x.2000.00403.x

[27] Varin, S., Cliquet, J., Personeni, E., Avice, J. and Lemauviel-Lavenant, S. (2010) How Does Sulphur Availability Modify N Acquisition of White Clover (Trifolium repens L.)? Journal of Experimental Botany, 61, 225-234. https://doi.org/10.1093/jxb/erp303

[28] Gaw, H.Z. and Soong, P.N. (1942) Nodulation and Dry Weight of Garden Peas as Affected by Sulfur and Sulfates. Agronomy Journal, 34, 100-103. https://doi.org/10.2134/agronj1942.00021962003400010010x

[29] Zhao, Y., Xiao, X., Bi, D. and Hu, F. (2008) Effects of Sulfur Fertilization on Soybean Root and Leaf Traits, and Soil Microbial Activity. Journal of Plant Nutrition, 31, 473-483. https://doi.org/10.1080/01904160801895001

[30] United States Department of Agriculture (USDA) (2019) Web Soil Survey. http://websoilsurvey.nrcs.usda.gov/app/WebSoilSurvey.aspx

[31] Carmer, S.G., Nyquist, W.E. and Walker, W.M. (1989) Least Significant Differences for Combined Analyses of Experiments with Two- or Three-Factor Treatment Designs. Agronomy Journal, 81, 665-672. https://doi.org/10.2134/agronj1989.00021962008100040021x

[32] Streeter, J.G. (1988) Inhibition of Legume Nodule Formation and $\mathrm{N}_{2}$ Fixation by Nitrate. Plant Science, 7, 1-23. https://doi.org/10.1080/07352688809382257

[33] Gibson, A.H. and Harper, J.E. (1985) Nitrate Effect on Nodulation of Soybean by Bradyrhizobium japonicum. Crop Science, 25, 497-501. https://doi.org/10.2135/cropsci1985.0011183X002500030015x

[34] Laysell, D.B. and Moloney, A.H.M. (1994) Dinitrogen Fixation. In: Boote, K.J., Bennett, J.M., Sinclair, T.R. and Paulsen, G.M., Eds., Physiology and Determination of Crop Yields, ASA, CSSA, SSSA, Madison, 311-336. https://doi.org/10.2134/1994.physiologyanddetermination.c21

[35] Hungria, M., Franchini, J.C., Campo, R.J., Crispino, C.C., Moraes, J.Z., Sibaldelli, R.N.R., Mendes, I.C. and Arihara, J. (2006) N Nutrition of Soybean in Brazil: Contributions of Biological $\mathrm{N}_{2}$ Fixation and N Fertilizer to Grain Yield. Canadian Journal of Plant Science, 86, 927-939. https://doi.org/10.4141/P05-098

[36] Mendes, I.C., Hungria, M. and Vargas, M.A.T. (2003) Soybean Response to Starter Nitrogen and Bradyrhizobium Inoculation on a Cerrado Oxisol under No-Tillage and Conventional Tillage Systems. Revista Brasileira de Ciência do Solo, 27, 81-87. https://doi.org/10.1590/S0100-06832003000100009

[37] Salvagiotti, F., Cassman, K.G., Specht, J.E., Walters, D.T., Weiss, A. and Doberman, A. (2008) Nitrogen Uptake, Fixation, and Response to Fertilizer N in Soybeans: A Review. Field Crops Research, 108, 1-13.

[38] Saito, A., Tanabata, S., Tanabata, T., Tajima, S., Ueno, M., Ishikawa, S., Ohtake, N., Sueyoshi, K. and Ohyama, T. (2014) Effect of Nitrate on Nodule and Root Growth of Soybean (Glycine max (L.) Merr.). International Journal of Molecular Sciences, 15, 4464-4480. https://doi.org/10.3390/ijms15034464

[39] Ohyama, T., Fujikake, H., Yashima, H., Tanabata, S., Ishikawa, S., Sato, T., Nishiwaki, T., Ohtake, N., Sueyoshi, K., Ishii, S. and Fujimaki, S. (2011) Effect of Nitrate on Nodulation and Nitrogen Fixation of Soybean. In: El-Shemy, H., Ed., Soybean Physiology and Biochemistry, Intech, Rijeka, 333-364. https://doi.org/10.5772/17992

[40] Neo, H.H. and Layzell, D.B. (1997) Phloem Glutamine and the Regulation of $\mathrm{O}_{2}$ 
Diffusion in Legume Nodules. Plant Physiology, 113, 259-267.

https://doi.org/10.1104/pp.113.1.259

[41] Bacanamwo, M. and Harper, J.E. (1997) The Feedback Mechanism of Nitrate Inhibition of Nitrogenase Activity in Soybean May Involve Asparagines and/or Products of Its Metabolism. Physiologia Plantarum, 100, 371-377. https://doi.org/10.1034/j.1399-3054.1997.1000220.x

[42] Gordon, A.J., Skøt, L., James, C.L. and Minchin, F.R. (2002) Short-Term Metabolic Responses of Soybean Root Nodules to Nitrate. Journal of Experimental Botany, 53, 423-428. https://doi.org/10.1093/jexbot/53.368.423

[43] Schuller, K.A., Minchin, F.R. and Gresshoff, P. (1988) Nitrogenase Activity and Oxygen Diffusion in Nodules of Soybean cv Bragg and a Supernodulating Mutant: Effect of Nitrate. Journal of Experimental Botany, 39, 865-877.

https://doi.org/10.1093/jxb/39.7.865 